\begin{tabular}{lllllllllll}
\hline $\mathrm{M}$ & $\mathrm{I}$ & $\mathrm{S}$ & $\mathrm{C}$ & $\mathrm{E}$ & $\mathrm{L}$ & $\mathrm{L}$ & $\mathrm{A}$ & $\mathrm{N}$ & $\mathrm{E}$ & $\mathrm{A}$
\end{tabular}

ANDRIJ BEZSMERTNYJ

Lwów

\title{
LWOWSKIE ORGANIZACJE KUPIECKIE W OKRESIE MIĘDZYWOJENNYM*
}

Zarys treści: Artykuł przedstawia lwowskie organizacje kupieckie działające w mieście w okresie międzywojennym, opisuje charakter stosunków pomiędzy stowarzyszeniami kupców oraz ich relacje z władzą i pozamiejscowymi organizacjami kupieckimi. Omawia problem wsparcia finansowego kupców, tworzenia spółdzielczych instytucji kredytowych i najważniejszych narzędzi wspierania drobnego handlu i rzemiosła. Ukazuje rolę Izby Przemysłowo-Handlowej Lwowa w życiu gospodarczym miasta.

The content outline: The article presents the types of Lviv's merchants' associations that operated in the city in the interwar period; it describes the nature of relationship between the trade associations, and their relations with the authorities and non-local merchant organisations. It discusses also the problem of financial support for merchants, creation of cooperative credit institutions, and the most important tools to promote small trade and crafts. It describes the role played by the Lviv Trade and Industry Chamber in the economic life of the city.

Słowa kluczowe: okres międzywojenny, Lwów, Lwowska Kongregacja Kupiecka, Lwowskie Stowarzyszenie Kupców, Związek Kupców Ukraińskich, Izba Przemysłowo-Handlowa

Keywords: interwar period, Lviv, Trade and Merchant Congregation, Lviv Merchant Association, Association of Ukrainian Merchants, Trade and Industry Chamber

* Artykuł powstał dzięki badaniom sfinansowanym ze środków funduszu stypendialnego Muzeum Historii Polski przyznanych na podstawie umowy stypendialnej nr MHP/17/2016. 
Handel odgrywał istotna rolę w gospodarce Lwowa. W 1931 r. na terenie miasta było zarejestrowanych około 25 tys. firm handlowych, które dawały utrzymanie około 65 tys. osób (15\% mieszkańców miasta). Zdecydowana większość przedsiębiorstw handlowych to były małe sklepy detaliczne, których właściciele nie zatrudniali pracowników, a co najwyżej korzystali z pomocy członków rodziny. Jednak obok tego działało kilkaset większych zakładów zajmujących się handlem hurtowym. Ponad połowa lwowian utrzymujacych się z handlu była wyznania mojżeszowego (prawie 40 tys.). Na drugim miejscu plasowali się rzymscy katolicy (16 tys.), a na trzecim grekokatolicy (7 tys. osób). Siła rzeczy aktywność licznych organizacji reprezentujacych interesy gospodarcze, a niekiedy i polityczne kupiectwa lwowskiego stanowi ważny aspekt historii Lwowa i zasługuje na bliższą analizę.

Tymczasem organizacje kupieckie Lwowa w okresie międzywojennym nie cieszyły się dotychczas większym zainteresowaniem badaczy. Podstawowe informacje dotyczące żydowskich organizacji kupieckich województwa lwowskiego w okresie międzywojennym (liczbę i lokalizację terytorialna) przedstawił Wacław Wierzbieniec ${ }^{1}$. Działalność Związku Kupców Ukraińskich (Sojuzu Ukrajinśkych Kupciw, SUK) opisał Tadeusz Filar ${ }^{2}$.

W artykule wykorzystano materiały archiwalne z: Centralnego Państwowego Archiwum Historycznego Ukrainy we Lwowie, Państwowego Archiwum Obwodu Lwowskiego, Archiwum Akt Nowych w Warszawie, Archiwum Żydowskiego Instytutu Historycznego oraz ze zbiorów Muzeum Niepodległości w Warszawie. Bazę źródłową uzupełniły materiały z prasy kupieckiej, m.in. z czasopisma „Kupiec Polski”, a także sprawozdania i protokoły posiedzeń Izby Przemysłowo-Handlowej i organizacji kupieckich Lwowa ${ }^{3}$.

\footnotetext{
${ }^{1}$ W. Wierzbieniec, Żydzi w województwie lwowskim w okresie międzywojennym. Zagadnienia demograficzne i społeczne, Rzeszów 2003.

${ }^{2}$ T. Filar, Ukraińskie galicyjskie sfery gospodarcze $w$ Drugiej Rzeczypospolitej, Kraków 2011.

${ }^{3}$ Sprawozdanie z czynności oraz o stanie gospodarczym w okregu Izby Przemystowo-Handlowej we Lwowie w roku 1935, Lwów 1936; Stenograficzny protokót ankiety $w$ sprawie położenia gospodarczego przemystu, handlu $i$ rękodzieła, odbytej $w$ dniach 21 i 22 listopada 1925 r. $w$ Izbie Handlowej i Przemystowej we Lwowie, Lwów 1926; Izba Przemystowo-Handlowa. Plenarne zebranie (1935, 18 grudnia; Lwów) Protokót, Lwów 1935; Sprawozdanie z czynności prezydium i wydziału Kongregacji Kupieckiej za czas od 16 października 1926 r. do 9 listopada 1929 r., Lwów 1929; Sprawozdanie Stowarzyszenia Kupców i Przemystowców Polskich Województw Południowo-Wschodnich z czynności za rok 1936, Lwów 1937.
} 


\section{Wielobranżowe organizacje kupieckie}

Kupiectwo lwowskie od najdawniejszych czasów starało się walczyć o swoje interesy nie tylko indywidualnie, ale także za pośrednictwem organizacji samorządowych - gildii. Na przełomie XIX i XX stulecia powstawać zaczęły nowoczesne stowarzyszenia społeczno-zawodowe, reprezentujące interesy różnych środowisk. Były wśród nich organizacje zrzeszające przedstawicieli konkretnych branż czy kategorii firm, ale też handlowców danego wyznania lub narodowości. Większość zaprzestała działalności w okresie I wojny światowej, ale po zakończeniu działań wojennych część wznowiła aktywność.

Najważniejszą organizacją skupiającą kupców żydowskich było Lwowskie Stowarzyszenie Kupców (w okresu międzywojennym używano również nazwy Lwowskie Zrzeszenie Kupców). Powstało jeszcze 1904 r. pod nazwą Towarzystwo Ochrony Drobnego Handlu ${ }^{4}$.

Po zakończeniu wojny w 1919 r. odbyło się pierwsze walne zgromadzenie członków Stowarzyszenia. Jego prezesem został Maurycy Rapaport, wiceprezesami: Natan Weinreb, Maks Finkelstein, Izak Bürger, Maks Wiesenberg i Ignacy Jäger. Członkami rady zostali m.in.: Salomon Bilbel, Zygmunt Brett, Teodor Dornhelm, Karol Eisenstein (stanał na czele Stowarzyszenia w 1926 r.). W 1939 r. do Stowarzyszenia należało 3 tys. kupców żydowskich (wielu z nich było członkami kilku organizacji jednocześnie) ${ }^{5}$. Na przykład kupiec Jakub Possament był jednocześnie członkiem Lwowskiego Stowarzyszenia Kupców oraz Stowarzyszenia Księgowych i Subiektów Handlowych.

Kupcy polscy, którzy posiadali średnie i większe przedsiębiorstwa detalicznej i hurtowej sprzedaży, od 1910 r. ${ }^{6}$ byli członkami Kongregacji Kupieckiej, która wyłoniła się ze Stowarzyszenia Wzajemnej Pomocy Kupców i Młodzieży Handlowej (zgodnie ze statutem Stowarzyszenia

${ }^{4}$ Założycielami byli kupcy: Adolf Auerbach, Adolf Eisenklam, Artur Awin, Leon Bauer, Adolf Czopp, Szymon Feller, Maurycy Kalisch, Markus Karol, Herman Lachs, Herman Hornung, Oziasz Messer, Hersz Mund, Maurycy Rapaport, Zygmunt Schaff, Maurycy Spiegel, Adolf Steinsberg, Abraham Tendler, Herman Tendler, Isak Schleier i in.; Dwudziestopięciolecie Lwowskiego Stowarzyszenia Kupców 1904-1929, Lwów 1929, s. 49.

5 W. Wierzbieniec, dz. cyt., s. 266.

${ }^{6}$ W 1675 r. we Lwowie założono Bractwo Młodzieży Kupieckiej. Od 1771 r. działało jak samodzielna korporacja, w 1886 r. zostało zreorganizowane w Stowarzyszenie Wzajemnej Pomocy Kupców i Młodzieży Handlowej. W 1910 r. przy nim organizowała się Kongregacja Kupiecka.

7 Polski Zwiazek Handlowców: Towarzystwo Zapomogowe we Lwowie, 1920-1930. Jednodniówka, Lwów 1930, s. 8. 
- zatwierdzonym przez wojewodę lwowskiego - jego zadaniem było dostarczenie informacji handlowej i wsparcie finansowe jego członków ${ }^{8}$ ).

W 1919 r. członkami Kongregacji byli m.in.: kupiec i fabrykant Franciszek Niewczyk, kupiec i introligator Leon Wattorski, Karol Homola, Aleksander Pfützner (właściciel domu handlowego „Pfützner i spółka”), Włodzimierz Iżycki, Adolf Łodel, Zenon Grocholski, Wacław Iwalski $^{9}$, fabrykanci i przemysłowcy: Józef Hecker, Józef Kotowicz, firma „J.A. Baczewski”, Tadeusz Höflinger (właściciel fabryki czekolady i słodyczy) ${ }^{10}$. Członkiem lwowskiej Kongregacji Kupieckiej mogła zostać osoba wyznania chrześcijańskiego, która samodzielnie zajmowała się legalnym handlem albo przemysłem ${ }^{11}$. W momencie zatwierdzenia statutu Kongregacji należało do niej 320 członków ${ }^{12}$.

Do Kongregacji mogli należeć także przedsiębiorcy spoza Lwowa. W latach 1926-1929 było ich 38 z: Brzeżan, Tarnopola, Kołomyi, Jaworowa, Rohatyna, Drohobycza i Sambora ${ }^{13}$. Liczba członków organizacji systematycznie rosła, nawet w okresie kryzysu - w latach 1933-1936

8 Archiwum Akt Nowych w Warszawie (dalej: AAN), zespół 100, Archiwum Ignacego Jana Paderewskiego. Korespondencja I.J. Paderewskiego od: polskich partii, organizacji, stowarzyszeń i instytucji, sygn. 2047, Stowarzyszenie Wzajemnej Pomocy Kupców i Młodzieży Handlowej (Lwów), Załączniki: Statut, Lwów, 1924 r., s. 16, L.1, k. 6.

${ }^{9}$ Kongregacja zrzeszała przedstawicieli dawnych polskich rodzin kupieckich. Na przykład kupiec Karol Klimowicz (1848-1889) był synem Teodora (1794-1874), który przyjechał do Lwowa z Łopatyna (pow. Brody). Karol Klimowicz miał pięcioro dzieci, m.in. syna Karola Stanisława (1875-1959), który odziedziczył sklep ojca. Studiował on na Politechnice Lwowskiej. Od 1904 r. pracował jako inżynier. W sierpniu 1914 r. został powołany do wojska. Uczestniczył w obronie Lwowa. Do 1929 r. pracował w Tymczasowym Wydziale Samorządowym we Lwowie; zob. Muzeum Niepodległości w Warszawie, Kolekcja Leopolis, zespół 37, Dokumenty rodziny Klimowiczów, sygn. 19, k. 53-56; sygn. 33, k. 88. Kupiec pochodzenia niemieckiego Ludwik Stadtmüller urodził się w 1811 r. w Stiechefstaett (Bawaria), w połowie XIX w. wraz ze swoją żoną Katarzyna z domu Gruber (ur. 1824 r.) przybył na ziemie polskie. Małżeństwo zamieszkało we Lwowie, gdzie od 1847 r. z powodzeniem prowadziło skład win przy ul. Krakowskiej. Jeden z synów Ludwika - również Ludwik (1857-1927) - rozwinął firmę i założył restaurację w Hotelu Francuskim przy pl. Mariackim. Rodzina Stadtmüllerów posiadała we Lwowie w różnych okresach: folwark pod miastem, cegielnię (1847-1912), restaurację i winiarnię na rynku (do 1938 r.) oraz winiarnię przy ul. Dominikańskiej, browar przy ul. Trybunalskiej i kawiarnię „Wiedeńska” (od 1902 r.).

${ }^{10}$ Centralne Państwowe Archiwum Historyczne Ukrainy we Lwowie (dalej: CPAHU), zespół 702, Kongregacja Kupiecka, sygn. 34, Lista członków Kongregacji Kupieckiej miasta Lwowa, k. 5.

11 Tamże, sygn. 1230, O działalności Kongregacji Kupców we Lwowie za lata 1927-1937, k. 6.

12 Tamże.

13 Sprawozdanie z czynności prezydium i wydziatu..., s. 23. 
- akces do niej zgłosiło 108 chętnych $^{14}$. W 1939 r. Kongregacja miała 19 oddziałów terytorialnych ${ }^{15}$.

Oprócz Kongregacji Kupieckiej we Lwowie działała jeszcze jedna wielobranżowa organizacja polskich kupców - Polskie Towarzystwo Chrześcijańskich Kupców Detalistów (w 1936 r. skupiało 300 członków ${ }^{16}$ ).

Ukraińskie kupiectwo Lwowa było reprezentowane przez jedna organizację - wspomniany już Związek Kupców Ukraińskich. Utworzono go w listopadzie 1923 r., a statut opracował Stepan Biljak. Pierwszym prezesem został Yewhen Martynec, jego zastępca Roman Zybuk (przewodniczył SUK w latach 1927-1928), a sekretarzem Dmytro Konjuch. W latach 20. Zwiazzek liczył 540 członków, w tym 233 ze Lwowa. Jego filie działały początkowo w: Przemyślu, Stanisławowie, Kołomyi i Samborze, a w latach 1928-1931 zostały otwarte kolejne, w: Sokalu, Nadwórnej, Trembowli, Stryju i Złoczowie ${ }^{17}$. Tylko w 1935 r. wstapiło do SUK 700 kupców, a liczba członków sięgnęła 2419. Na początku 1939 r. do Związku należało 5 tys. członków i miał on 38 filiii ${ }^{18}$.

Z początkiem II wojny światowej SUK przestał działać, jednak podczas okupacji niemieckiej wznowił aktywność. Na początku 1942 r. przy Ukraińskim Komitecie Lwowa stworzono Zjednoczenie Pracy Kupców Ukraińskich, na jego czele stanął Jewstahij Dumyn ${ }^{19}$. Lwowska Kongregacja Kupiecka również chciała wznowić działalność (członkowie Kongregacji Jan Sudhoff i Tadeusz Höflinger otrzymali potwierdzenie swego niemieckiego pochodzenia) ${ }^{20}$. Na początku sierpnia $1941 \mathrm{r}$. były prezes Kupieckiej Kongregacji Jan Kanty Pfau wysłał do administracji niemieckiej list, wskazując, że Kongregacja działała we Lwowie od 1673 do września 1939 r. i zrzeszała tylko kupiectwo chrześcijańskie. Jednak w październiku tegoż roku otrzymał odmowę wznowienia działalności ${ }^{21}$.

${ }^{14}$ Państwowe Archiwum Obwodu Lwowskiego (dalej: PAOL), zespół 110, Lwowskie Miejskie Starostwo, sygn. 300, O rejestracji Kongregacji Kupieckiej we Lwowie, k. $3-4$.

15 „Biuletyn Kongregacji Kupieckiej we Lwowie” 1939, nr 1.

16 Spis organizacji gospodarczych opracowany na podstawie materiałów ankietowych zebranych przez izby przemystowo-handlowe, Warszawa 1936, s. 215-220.

17 В.Т. Несторович, Украӥнські купиі і промисловці в Західній Україні 1920 -1945, Торонто-Чікаго 1977, s. 26.

18 Tamże, s. 41.

19 Tamże, s. 32.

${ }^{20}$ Archiwum Żydowskiego Instytutu Historycznego, Teka lwowska, sygn. 229/16, Polacy pochodzenia niemieckiego za lata 1941-1942, k. 1-7.

${ }^{21}$ AAN, zespół 540, Starostwo Miejskie we Lwowie, sygn. 244, Odmowa rejestracji Kongregacji Kupieckiej we Lwowie. Korespondencja, k. 2. 


\section{Związki zawodowe kupców według ich specjalizacji handlowej}

Wśród stowarzyszeń kupieckich były również organizacje branżowe żydowskich kupców. Do Wschodnio-Małopolskiego Związku Eksporterów Jaj należało 63 członków ${ }^{22}$. Z kolei Związek Kupców Zbożem, Przetworami i Produktami Rolnemi w 1923 r. miał 400 członków ${ }^{23}$ (wyłącznie kupców wyznania mojżeszowego).

W mieście działały również organizacje specjalistyczne, które skupiały tylko polskich kupców: Towarzystwo Eksporterów Lnu i Konopi Południowych Ziem Polski (w 1936 r. skupiało 420 członków ${ }^{24}$ ), Zrzeszenie Eksporterów i Kupców Odpadków Włókienniczych (w sprawozdaniu z działalności za 1937 r. zaznaczono, że jego celem jest uregulowanie spraw handlu i eksportu odpadków włókienniczych oraz jego rozwój) ${ }^{25}$, Związek Lwowskich Kupców Cukrowych „Słodycz” ${ }^{26}$ oraz Lwowski Związek Kupców Skór „Pellis”27. W czerwcu 1924 r. wznowiło swoją działalność Małopolskie Towarzystwo Samodzielnych Kupców Rogacizny $^{28}$. Od 1929 r. funkcjonował Małopolski Syndykat Fabrykantów i Kupców Alkoholu ${ }^{29}$ oraz Związek Kupców, Fabrykantów i Rękodzielników „Łącznośćc”30.

Do polskich kupieckich organizacji specjalistycznych, których członkami mogli być kupcy wyznania mojżeszowego, należał Syndykat Interesantów Drzewnych (w 1931 r. miał 111 członków) ${ }^{31}$.

${ }^{22}$ PAOL, zespół 110, Lwowskie Miejskie Starostwo, sygn. 468, Spis organizacji handlowych i przemysłowych za 1934 r., k. 24.

${ }_{23}$ Spis organizacji gospodarczych..., s. 20.

${ }_{24}$ Tamże, s. 420.

25 AAN, zespół 512, Ambasada RP w Berlinie, sygn. 22, Zrzeszenie Eksporterów i Kupców Odpadków Włókienniczych we Lwowie - sprawozdanie z działalności za 1937 r., k. 3, 4.

${ }^{26}$ AAN, zespół 213, Rada Spółdzielcza w Warszawie, sygn. 10121, „Słodycz” Związek Lwowskich Kupców Cukrowych. Stowarzyszenie we Lwowie, bpag.

27 Tamże, sygn. 10019, „Pellis” Lwowski Związek Kupców Skór, k. 8.

${ }_{28}$ PAOL, zespół 1, Akta Lwowskiego Urzędu Wojewódzkiego, sygn. 827, O działalności towarzystwa handlowców rogacizną we Lwowie, k. 57, 147.

${ }_{29}$ Tamże, sygn. 1309, O odkryciu towarzystw i związków, t. 2, 1929 r., k. 39.

30 Tamże, sygn. 698, Rejestracja Towarzystwa Drobnych Kupców i Handlowców we Lwowie, za lata 1922-1929, k. 22.

31 Tamże, sygn. 1933, Sprawozdanie z działalności syndykatu handlu drzewem za lata 1931-1937, k. 6, 31. 


\section{Organizacje drobnych kupców i handlowców}

W mieście istniało również kilka związków i towarzystw, które zrzeszały drobnych kupców i handlowców: Towarzystwo Handlowców Nafta $^{32}$ (od 1918 r.), Towarzystwo Pomocy Wzajemnej Drobnych Kupców Chrześcijańskich w Galicji3i ${ }^{33}$ (założone w 1919 r.), Polski Zwiazek Handlowców (założony przez Władysława Webera w listopadzie 1920 r.), który liczył około 250 członków, w tym wielu kupców: Stanisław Barwik, Leon Fuks, Józef Konopasek, Józef Maziarz, Antoni Moor, Mikołaj Olech, Władysław Stępień, Bolesław Tyński (wielu z nich było jednocześnie członkami Kongregacji Kupieckiej ${ }^{34}$ ). Od 1925 r. w mieście działały następujące zrzeszenia: Towarzystwo Drobnych Kupców (prezesem był Zygmunt Vogel) ${ }^{35}$, Towarzystwo Przedstawicieli Handlowych

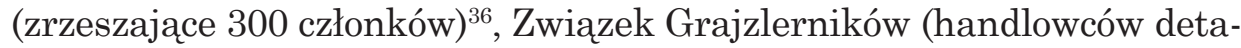
licznych towarami spożywczymi $)^{37}$, a także Towarzystwo Wzajemnej Pomocy Handlowców Obwodowych (od 1926 r.) ) $^{38}$.

Liczba drobnych organizacji kupieckich rosła z roku na rok. W $1929 \mathrm{r}$. w Urzędzie Województwa zarejestrowano: Związek Drobnych Handlowców i Straganiarzy (1200 członków) ${ }^{39}$, Związek Handlowców Bitym Drobiem (w 1934 r. liczył 140 członków) ${ }^{40}$, Towarzystwo Kupców Kredytowych, Profesjonalny Związek Agentów i Komiwojażerów (z prezesem Bolesławem Straisenbergiem na czele) ${ }^{41}$. Od 1932 r. działało również Towarzystwo Drobnych Kupców i Handlowców ${ }^{42}$ (w 1939 r. liczyło 250 członków), a od 1937 r. Towarzystwo Obwodowych Handlowców

${ }^{32}$ PAOL, zespół 110, Lwowskie Miejskie Starostwo, sygn. 772, Towarzystwo Handlowców Naftą we Lwowie, sprawozdanie za lata 1936-1937, k. 1.

${ }^{33}$ Tamże, sygn. 655, Rejestracja Towarzystwa Pomocy Wzajemnej Drobnych Kupców Chrześcijańskich Galicji we Lwowie, za lata 1919-1931, k. 54.

${ }^{34}$ Polski Zwiazek Handlowców..., s. 1, 4, 6.

35 Spis organizacji gospodarczych..., s. 19.

36 PAOL, zespół 1, Akta Lwowskiego Urzędu Wojewódzkiego, sygn. 93, O działalności Towarzystwa Przedstawicieli Handlowych we Lwowie, za lata 1908-1921, k. 164.

37 „Kupiec Polski”, I 1926, s. 3.

38 PAOL, zespół 110, Lwowskie Miejskie Starostwo, sygn. 668, Towarzystwo Wzajemnej Pomocy Handlowców Obwodowych, sprawozdanie za lata 1926-1939, k. 62.

39 Spis organizacji gospodarczych..., s. 38.

${ }^{40}$ PAOL, zespół 110, Lwowskie Miejskie Starostwo, sygn. 468, Spis organizacji handlowych i przemysłowych za 1934 r., k. 15.

${ }^{41}$ Tamże, k. 30.

42 PAOL, zespół 110, Lwowskie Miejskie Starostwo, sygn. 698, Towarzystwo Drobnych Kupców i Handlowców, sprawozdanie za lata 1932-1937, k. 1-2. 
Owocami ${ }^{43}$, a także Chrześcijański Związek Drobnych Kupców i Handlowców ${ }^{44}$ (zrzeszał 180 członków).

\section{Wspólne organizacje kupców i przemysłowców}

W okresie międzywojennym we Lwowie działały wspólne organizacje kupców i fabrykantów. W szczególności należy wspomnieć Centralny Związek Kupców i Przedsiębiorców, założony w 1912 r. przez architekta i właściciela przedsiębiorstwa budowlanego Michała Ulama, który kierował nim do 1938 r..$^{45}$ Należało do niego 150 żydowskich kupców i fabrykantów (w 1939 r. przystapiło do niego jeszcze 525 żydowskich handlowych i przemysłowych przedsiębiorstw z województw lwowskiego, stanisławowskiego i tarnopolskiego ${ }^{46}$. Funkcjonowała ponadto Organizacja Żydowskich Kupców i Fabrykantów, do 1926 r. nią kierował Maurycy Rapaport, a w latach 30. Wiktor Chajes i wiceprezesi: Julian Bussgang, Michał Hackel, Maurycy Mund, Ignacy Menkes ${ }^{47}$ (w 1936 r. organizacja liczyła 316 członków) ${ }^{48}$. Odrębną organizację stworzyli żydowscy producenci i kupcy wyrobów złotych i srebrnych - Związek Producentów i Kupców Wyrobów z Szlachetnych Metalów (308 członków) ${ }^{49}$.

Spośród polskich kupiecko-przemysłowych organizacji we Lwowie działało jeszcze Stowarzyszenie Polskich Kupców i Przemysłowców Województw Południowo-Wschodnich ${ }^{50}$. Należało do niej 650 osób podzielonych na sekcje: metalowa, odzieżowa, owocowa, spożywcza, piekarska, przemysłową (na czele której stanął Stanisław Dąbrowski), handlowa (z prezesem Michałem Zaleskim na czele) i drobnego kupiectwa (pod kierownictwem Mieczysława Dziekana) ${ }^{51}$.

${ }^{43}$ Tamże, sygn. 540, Towarzystwo Obwodowych Handlowców Owocami, sprawozdanie za lata 1937-1939, k. 1.

${ }_{44}$ Tamże, sygn. 514, Chrześcijański Związek Drobnych Kupców i Handlowców, sprawozdanie za lata 1930-1939, k. 1-2.

${ }^{45}$ W. Wierzbieniec, dz. cyt., s. 244.

${ }^{46}$ Tamże.

${ }^{47}$ Sprawozdanie z czynności oraz o stanie gospodarczym..., s. 1.

48 Spis organizacji gospodarczych..., s. 36.

${ }^{49}$ PAOL, zespół 1, Akta Lwowskiego Urzędu Wojewódzkiego, sygn. 1245, Spis organizacji kupieckich, t. 1, 1928 r., k. 56.

${ }^{50}$ PAOL, zespół 110, Lwowskie Miejskie Starostwo, sygn. 468, Spis organizacji handlowych i przemysłowych za 1934 r., k. 24; Sprawozdanie Stowarzyszenia Kupców i Przemysłowców..., s. 18-26.

${ }^{51}$ PAOL, zespół 1, Akta Lwowskiego Urzędu Wojewódzkiego, sygn. 2355, Sprawozdanie o działalności Stowarzyszenia Polskich Kupców i Przemysłowców za lata 1934-1939, k. 31. 


\section{Formy wsparcia finansowego kupców}

Kupcy lwowscy organizowali także spółdzielcze instytucje kredytowe. Taki właśnie charakter miał utworzony w 1921 r. Związek Kupców. Spółdzielnią kierował prezes Kongregacji Kupieckiej - Ludwik Hoszowski $^{52}$. W styczniu 1922 r. wznowiła swoją działalność Kredytowa Spółdzielnia Kupców, Fabrykantów i Rzemieślników (założona w 1901 r.), która przyznawała polskim kupcom kredyty i pomagała w zakładaniu składów handlowych i sklepów. Udział członkowski wynosił 300 marek polskich. Dyrektorami spółdzielni zostały kupcy Ignacy Hader i Czesław Bürger ${ }^{53}$.

W 1924 r. stworzona została Spółdzielnia Kupców Spożywczych, której członkami założycielami byli kupcy żydowscy ${ }^{54}$. Wśród założycieli Kasy Pożyczkowej Kupców Drobnych znaleźli się zaś Leon Appel i Henryk Probst. W latach 1930-1934 we Lwowie działały też towarowo-bankowe spółdzielnie „Unitas” ${ }^{55}$ i „Unia” ${ }^{56}$.

Przy niektórych organizacjach kupieckich funkcjonowały spółdzielnie sprzedaży towarów na raty. Na przykład przy Stowarzyszeniu Polskich Kupców i Przedsiębiorców Województw Południowo-Wschodnich zorganizowano spółdzielnię wydająca członkom asygnaty na ratalny zakup towarów. Jej członkami mogły być tylko osoby polskiego pochodzenia ${ }^{57}$. Organizacje kupieckie tworzyły również własne hurtownie. Pierwsza hurtownia kupców towarów spożywczych i mieszanych zrzeszała 30 członków, których firmy działały jeszcze przed wojną ${ }^{58}$.

Centrala Bezprocentowych Kas Pożyczkowych „Gmilath Chesed” („Pożyczka Miłosierdzia”) dla Małopolski Wschodniej we Lwowie rozpoczęła swoją działalność w 1927 r. Głównym jej celem była pomoc dla drobnych przedsiębiorców i kupców żydowskich poprzez udzielanie im bezprocentowych pożyczek (a niekiedy także datków). Centrala czerpała fundusze w pierwszym rzędzie z zasobów Amerykańsko-Żydowskiego Połączonego Komitetu Rozdzielczego Joint (American Jewish

${ }^{52}$ AAN, zespół 213, Rada Spółdzielcza w Warszawie, sygn. 10400, Związek kupców we Lwowie, bpag.

${ }^{53}$ Tamże, sygn. 10300, Kredytowa Spółdzielnia Kupców, Fabrykantów i Rzemieślników, bpag.

${ }_{54}$ Tamże, sygn. 10172, Spółdzielnia Kupców Spożywczych, bpag.

55 Tamże, sygn. 9857, Kooperatywa towarowo-bankowa „Unitas”, k. 2.

56 Tamże, sygn. 9856, Kooperatywa towarowa „Unia”, k. 1, 2.

57 Tamże, sygn. 10209, Spółdzielnia Sprzedaży Ratalnej przy Stowarzyszeniu Polskich Kupców i Przemysłowców Województw Południowo-Wschodnich, k. 13.

58 Tamże, sygn. 10026, Pierwsza Hurtownia Kupców Lwowskich Towarzystw Spożywczych i Mieszanych we Lwowie, bpag. 
Joint Distribution Committee $)^{59}$. Dochód pochodził także ze składek członków i darowizn oraz - na podstawie odpowiedniego rozporządzenia Ministerstwa Spraw Wewnętrznych - subsydiów z kasy rady miasta Lwowa i rad powiatowych. Do końca 1927 r. „Gmilath Chesed” we Lwowie otrzymała $141087 \mathrm{zł}^{60}$.

\section{Stosunki pomiędzy stowarzyszeniami kupieckimi}

Organizacje kupieckie i kupiecko-przemysłowe działające we Lwowie współpracowały ze sobą w sytuacji zagrożenia interesów kupieckich. Było to widoczne np. w marcu 1925 r., w czasie dyskusji nad kształtem wprowadzanego właśnie podatku przemysłowego. Zorganizowano wówczas wiec, w którym uczestniczyli kupcy wszystkich działających w mieście korporacji. Prowadzili go: Maks Machler (członek Lwowskiego Stowarzyszenia Kupców) oraz przedstawiciele polskich i ukraińskich organizacji kupieckich: Ignacy Menkes (z Centralnego Zwiąku Kupców i Fabrykantów), Aleksander Zunin (z Towarzystwa Przedstawicieli Handlowych Lwowa), Eugeniusz Ticker (z Towarzystwa Handlowców i Straganiarzy Lwowa), Dmytro Steckiw (ze Związku Kupców Ukraińskich ${ }^{61}$. Działacze tych stowarzyszeń spotykali się w miarę regularnie i starali się wypracować rozwiązania korzystne dla wszystkich kupców poszczególnych branż ${ }^{62}$. I tak Centralny Związek Kupców i Fabrykantów zorganizował konferencję kupców zajmujących się sprzedażą odzieży (wśród zaproszonych byli kupcy żydowscy i innych narodowości). Była też pewna grupa firm, w których zarządach zasiadali przedstawiciele różnych narodowości i wyznan. W Syndykacie Eksporterów Produktów Rolniczych - zdominowanym przez Polaków - zasiadł Celestyn Frankel, na czele Związku Polskich Eksporterów Chmielu staną kupiec Zygmunt Flecker, członkiem Syndykatu Interesantów Drzewnych był Szymon Ulam, a w Towarzystwie Przedstawicieli Handlowych pracowali kupcy Julian Bussgang i Maks Machler ${ }^{63}$. Również kupcy ukraińscy nawiązywali kontakty z polskimi organizacjami kupieckimi. W latach 30. członkami Kongregacji Kupieckiej zostało kilku Ukraińców (jednocześnie byli oni członkami SUK): Jewstahij Dumyn,

\footnotetext{
59 „Chwila”, XII 1931, s. 14.

${ }^{60}$ W. Wierzbieniec, dz. cyt., s. 343.

61 „Kupiec Polski”, I 1926, s. 3.

62 „Front Gospodarczy”, IX 1934, s. 7-8.

${ }^{63}$ W. Wierzbieniec, dz. cyt., s. 266.
} 
Oleksander Onys'ko, Jewhen Stefanowycz i Julian Lomaga ${ }^{64}$. Jednak prasa ukraińska negatywnie oceniła ich decyzje ${ }^{65}$.

Przedstawiciele żydowskich i polskich organizacji kupieckich chcieli zrealizować ideę stworzenia wspólnej dla wszystkich organizacji kupieckiej. Tak sytuację oceniano w „Tygodniu Kupieckim”: „Nasze miasto dłuższy czas cierpi od nadmiaru kupieckich organizacji. Podział kupiectwa na różne drobne organizacje nie ma racji z przyczyn finansowych"66. Jednak członkowie Lwowskiego Stowarzyszenia Kupców uważali, że na drodze do zjednoczenia stoi negatywny stosunek niektórych polskich organizacji (w szczególności Kongregacji Kupieckiej) do handlowców żydowskich. Przedstawiciele Kongregacji deklarowali jednak gotowość do stworzenia wspólnej organizacji, w szczególności Jan Sudhoff, który w swoim wywiadzie dla prasy stwierdził nawet, że to jego marzenie ${ }^{67}$.

Z drugiej strony w kwietniu 1928 r. w „Tygodniu Kupieckim” opublikowano artykuł pt. Nacjonalizm organizacji kupieckich. Jego autor podkreślał, że żydowskie organizacje kupieckie, w przeciwieństwie do polskich, nie podkreślają swojego charakteru religijnego czy narodowego ${ }^{68}$.

Kongregacja Kupiecka nie tylko odmawiała prawa przynależności kupcom niechrześcijańskim, ale nawet nawoływała do ograniczania praw handlu żydowskiego. Przez cały okres międzywojenny domagała się konsekwentnego przestrzegania państwowego zakazu prowadzenia działalności handlowej w święta religijne i niedziele. Organizowała też różne akcje wymierzone w konkurentów żydowskich. Na walnym zgromadzeniu w 1927 r. zaprotestowano przeciwko przypadkom łamania ustawowego zakazu handlu w święta chrześcijańskie przez kupców żydowskich ${ }^{69}$. Politycy i przedsiębiorcy żydowscy postrzegali zakaz handlu w niedziele i święta chrześcijańskie jako represję polityczną i próbę realizacji hasła „odżydzenia handlu"

W miarę upływu lat polskie organizacje kupieckie brały coraz aktywniejszy udział w akcji antysemickiej. Na stronach polskiej prasy kupieckiej publikowano artykuły o wyraźnie antyżydowskim charakterze ${ }^{71}$.

${ }^{64}$ CPAHU, zespół 702, Kongregacja Kupiecka, sygn. 24, Listy do nowych członków Kongregacji Kupieckiej, za 1934 r., k. 30.

65 B.T. Несторович, dz. cyt., s. 208.

${ }_{66}$ Za: „Kupiec Polski”, V 1934, s. 8.

${ }^{67}$ „Handel - Przemysł - Rękodzieło”, VI 1926, s. 7.

${ }^{68}$ Za: „Kupiec Polski”, I 1932, s. 1.

69 A. Biedrzycka, Kalendarium Lwowa 1918-1939, Kraków 2012, s. 356.

70 Tamże, s. 269.

71 Tamże, s. 223. 
Głoszono pogląd, że polonizacja handlu będzie sprzyjać rozwojowi kraju - „kiedy urzędnik i kupiec zostana dziećmi jednego narodu” ${ }^{2}$. W listopadzie 1937 r. w Warszawie odbył się Kongres Kupców Chrześcijańskich Polski. Jego uczestnicy (w tym delegaci Kongregacji Kupieckiej) doszli do wniosku, że liczebna przewaga kupców żydowskich prowadzi do upadku gospodarczego kraju ${ }^{73}$. Zgłoszono postulat, by instytucje państwowe i samorządowe oraz przedsiębiorstwa należące do chrześcijan utrzymywały kontakty gospodarcze wyłącznie z przedsiębiorcami i kupcami chrześcijańskimi ${ }^{74}$.

Kupcy żydowscy negatywnie reagowali na żądania przedstawicieli polskiego kupiectwa dotyczące nacjonalizacji handlu przez kupców polskich. Uważali, że ich realizacja nie tylko szkodziłaby interesom ludności żydowskich, ale też sprzyjałaby umocnieniu biurokracji i etatyzacji ${ }^{75}$.

W środowisku polskiego kupiectwa we Lwowie trwał w latach 30. proces konsolidacji organizacyjnej. Do Kongregacji Kupieckiej przystapiło Towarzystwo Kupców i Przemysłowców oraz Polski Związek Handlowców ${ }^{76}$ (w 1932 r. skupiał 200 członków-kupców wyznania rzymskokatolickiego ze Lwowa i przedmieść, którzy posiadali świadectwa handlowo-przemysłowe II, III i IV kategorii) ${ }^{77}$. Dwóch jego członków - Adolf Lödl i Jan Wnuk - weszło do władz Kongregacji. W sierpniu 1934 r. doszło do przyłączenia Chrześcijańskiego Związku Kupców, który zajmował się sprzedażą materiałów opałowych ${ }^{78}$. Jako kolejne akces do Kongregacji Kupieckiej zgłosiło Towarzystwo Kupców Polskich (prezesem był Stanisław Bieńkowski), a w lutym 1935 r. Towarzystwo Chrześcijańskich Kupców-Detalistów (200 członków z Kazimierzem Maksymowiczem na czele ${ }^{79}$. Polska prasa pisała wówczas: „Dwie największe i najważniejsze chrześcijańskie kupieckie organizacje Lwowa, które do niedawna były wrogami na polu ideowym i programowym połączyły się. Nie można również nie życzyć, żeby nastąił moment, kiedy wszystkie organizacje kupieckie we Lwowie, i na

\footnotetext{
72 Tamże, s. 275.

${ }^{73}$ Problemy gospodarcze Drugiej Rzeczypospolitej, red. K. Kozłowski, Warszawa 1989, s. 163.

${ }^{74}$ J. Tomaszewski, Handel prywatny $w$ Polsce $w$ latach 1936-1939, w: Drobnomieszczaństwo XIX i XX wieku. Studia, t. 1, red. S. Kowalska-Glikman, Warszawa, 1984, s. 224.

75 T. Filar, dz. cyt., s. 275.

${ }^{76}$ CPAHU, zespół 702, Kongregacja Kupiecka, sygn. 15, Rozporządzenia Rady Głównej Związku Kupiectwa Polskiego w Warszawie za 1932 r., k. 16.

77 Tamże.

78 Tamże, k. 9.

${ }^{79}$ Sprawozdanie z czynności oraz o stanie gospodarczym..., s. 2.
} 
prowincji bez względu na wiarę i narodowość ich członków połączą się w jedyną organizację" Kongregacji Kupieckiej również miała pomóc polskiemu kupiectwu $\mathrm{w}$ walce o nacjonalizację handlu ${ }^{81}$.

\section{Współpraca z pozamiejscowymi organizacjami kupieckimi}

Lwowska Kongregacja Kupiecka ściśle współpracowała z Kupiecka Kongregacja miasta Krakowa i wydawała wraz z nią czasopismo „Kupiec Polski”82 (publikowane od 1907 r. do początku I wojny światowej, druk wznowiono w styczniu 1925 r.). W gazecie drukowano artykuły o gospodarce i handlu. W obu Kongregacjach również obchodzonyo Dzień Kupca - wyznaczony na 8 grudnia ${ }^{83}$ (w dzień wspomnienia Matki Bożej Niepokalanie Poczętej).

Od pierwszych lat niepodległości swoje oddziały lokalne organizowały we Lwowie także ogólnopolskie organizacje kupieckie, których centrala znajdowała się z reguły w Warszawie. Dotyczyło to zarówno organizacji polskich, jak i żydowskich. Wśród nich były: Warszawski Związek Detalicznych i Drobnych Kupców Polski, Fachowy Zwiazek Agentów i Komiwojażerów Rzeczypospolitej Polskiejes, a także Warszawskie Towarzystwo Kupców Polskich (340 członków).

Kongregacja Kupiecka negatywnie odnosiła się do pomysłu tworzenia oddziałów organizacji ogólnopolskich. W 1922 r. doszło do otwartego sporu między nią a Towarzystwem Kupców Polskich z centrala w Warszawie. Władze Kongregacji uważały, że Towarzystwo powinno uznać Kongregację za reprezentanta interesów kupiectwa wschodniogalicyjskiego i działać za jej pośrednictwem, tworzenie lokalnych struktur organizacyjnych tylko bowiem wzmocni wewnętrzną konkurencję i pogłębi chaos $\mathrm{w}$ środowisku kupieckim ${ }^{85}$. Towarzystwo

80 „Handel - Przemysł - Rękodzieło”, VI 1926, s. 7.

81 T. Filar, dz. cyt., s. 275.

${ }^{82}$ I. Kawalla, Działalność Krakowskiej Kongregacji Kupieckiej w latach 1918-1939 $w$ świetle rocznych materiałów sprawozdawczych, „Annales Universitatis Paedagogicae Cracoviensis. Studia Historica" 9, 2010, s. 52-53.

83 Tamże.

${ }^{84}$ PAOL, zespół 110, Lwowskie Miejskie Starostwo, sygn. 468, Spis organizacji handlowych i przemysłowych za 1934 r., k. 23-37.

${ }^{85}$ CPAHU, zespół 702, Kongregacja Kupiecka, sygn. 1230, O działalności Kongregacji Kupców we Lwowie za lata 1927-1937, k. 4. 
było jednak zbyt ważną instytucja, by Kongregacja mogła pozostawać z nim w długotrwałym konflikcie, dlatego też członkowie Kongregacji wzięli udział w uroczystym otwarciu lwowskiego oddziału Towarzystwa Kupców Polskich we Lwowie (na czele której stanęli Edmund Riedl i Antoni Uwiera ${ }^{86}$ ).

Związek Kupców Ukraińskich współpracował ze Związkiem Ukraińsko-Amerykańskich Kupców i Fabrykantów (założonym w 1932 r. przez ukraińskich kupców, którzy wyemigrowali do USA). Utrzymywał również kontakt z 52 ukraińskimi kupcami i przemysłowcami z: Niemiec, Czechosłowacji, Rumunii i Francji oraz z krajów Ameryki Północnej i Południowej: USA, Kanady, Argentyny i Brazylii ${ }^{87}$.

W czasach kierownictwa Ludwika Hoszowskiego w latach 1922-1923 Kongregacja Kupiecka współpracowała zaś z Komisja Handlowo-Przemysłowa, która zajmowała się stworzeniem Polsko-Francuskiej Izby Handlowej i aktywnie współpracowała w sprawie podpisania umów handlowych z Austrią i Niemcami ${ }^{88}$.

\section{Relacje z władzą}

Władza państwowa starała się kontrolować działalność kupieckich organizacji Lwowa i przeciwdziałać niektórym formom ich aktywności. I tak w 1925 r. władze administracyjne, zaniepokojone siłą protestów przeciwko wprowadzaniu podatku przemysłowego, zagroziły żydowskim organizacjom kupieckim, że w przypadku kontynuowania akcji antypodatkowych zostaną one rozwiązane.

Pod bacznym nadzorem policji pozostawali również członkowie Związku Kupców Ukraińskich. Początkowo władze ograniczały jego działalność do województw lwowskiego, stanisławowskiego i tarnopolskiego. Jednak w 1928 r. prezes SUK Hryhorij Hanulak otrzymał pozwolenie na działalność Związku na całym terytorium Polski. Sprzyjał temu fakt, że ośrodek wołyński SUK był neutralny pod względem politycznym i nie pozostawał pod wpływem Komunistycznej Partii Zachodniej Ukrainy. Na pozytywną decyzję władz wpłynęły również kontakty Hanulaka z polskimi przedsiębiorcami i władzami Izby Przemysłowo-Handlowej. Jednak w 1936 r. ponownie

86 Stenograficzny protokót ankiety..., s. 2.

${ }^{87}$ T. Filar, dz. cyt., s. 218.

${ }^{8}$ CPAHU, zespół 702, Kongregacja Kupiecka, sygn. 1230, O działalności Kongregacji Kupców we Lwowie za lata 1927-1937, k. 49. 
ograniczono zasięg terytorialny działalności Związku. We wrześniu jego władze wydały oświadczenie, w którym czytamy: „Po dłuższym czasie województwo lwowskie zwróciło statut Związku Kupców Ukraińskich i wymaga wniesienia formalnych zmian do niego, zwłaszcza zmiany paragrafu statutu o tym, że działalność SUK jest dozwolona na terytorium całej Polski" "89. Zakaz tworzenia filii Związu w województwie wołyńskim ponowiono, ponieważ po śmierci Józefa Piłsudskiego polityka wobec województwa znalazła się w rękach wojskowych $^{90}$. Przed początkiem II wojny światowej władza zabroniła z powodów politycznych działalności kilku filii SUK na terenie Galicji (m.in. w Tarnopolu).

W latach 30. władze państwowe podjęły próby utworzenia obowiązkowego samorządu gospodarczego. Spotkało się to z niechęcia ze strony kupców zarówno polskich, jak żydowskich ${ }^{91}$.

Organizacje kupieckie aktywnie współpracowały z Ministerstwem Skarbu i Gospodarki. Przedstawiciele Lwowskiego Stowarzyszenia Kupców za pośrednictwem Organizacji Towarzystw Gospodarczych Galicji Wschodniej (która wchodziła w skład Rady Przemysłowej i Handlowej przy Ministerstwie Przemysłu i Handlu oraz Rady Gospodarczej przy Ministerstwie Skarbu) domagali się obniżenia podatków, nisko oprocentowanych kredytów, wydłużenia godzin handlu, unieważnienia ustawy o zamknięciu sklepów w święta chrześcijańskie i niedziele (gdy kupcy żydowscy zamykali sklepy w sabat i święta mojżeszowe chrześcijanie handlowali bez przeszkód), wzmocnienia walki z handlem nielegalnym i pokatnym.

Lwowskie organizacje kupieckie aktywnie uczestniczyły też w dyskusjach nad kluczowymi problemami kraju. W 1928 r. we Lwowie odbyło się walne zgromadzenie kupiectwa żydowskiego poświęcone analizie bilansu handlowego Polski oraz ocenie skutków wprowadzenia podatku przemysłowego. W swoim przemówieniu prezes Lwowskiego Stowarzyszenia Kupców Karol Eisenstein podkreślał wspieranie przez kupiectwo żydowskie krajowych producentów.

W kwietniu 1935 r. członkowie Stowarzyszenia i Centralny Związek Żydowskich Kupców i Fabrykantów Lwowa wsparli projekt ustawy o kredytowaniu 3\% pożyczki przeznaczonej na zwiększenie produkcji i obrotów handlowych przedsiębiorstw handlowych. Wśród 22 organizacji, które poparły projekt, były również: Lwowska Kongregacja

\footnotetext{
${ }^{89}$ В.Т. Несторович, dz. cyt., s. 115.

90 T. Filar, dz. cyt., s. 218.

${ }^{91}$ „Kupiec Polski”, 20 V 1934, s. 6.
} 
Kupiecka, Stowarzyszenie Polskich Kupców i Przemysłowców Województw Południowo-Wschodnich oraz Związek Kupców Ukraińskich (oprócz tego przywódcy SUK brali udział w pracach komisji państwowych, np. Jarosław Skoplak działał w Głównej Radzie Gospodarczejej ${ }^{92}$. Z drugiej strony kupcy przychylnie odnieśli się do projektu wojewody lwowskiego z 1938 r., który zakładał stworzenie we Lwowie regionalnego centrum koordynującego rozwój gospodarczy województw południowo-wschodnich.

\section{Działalność Izby Przemysłowo-Handlowej}

$\mathrm{Na}$ początku lat 20. ponownie zaczęła funkcjonować Izba Przemysłowo-Handlowa Lwowa. Od 1927 r. działała ona na podstawie statutu zawartego w rozporządzeniu Prezydenta Rzeczypospolitej Polskiej (z 15 VII 1927 r.) jako Izba Przemysłowo-Handlowa. Składała się z sekcji handlowej i przemysłowej, których członków wybierano spośród kupców i przemysłowców na 6 lat ${ }^{93}$. W jej skład mogło wchodzić maksymalnie 84 radców - 70 było wybieranych, 7 mianował minister przemysłu i handlu, a kolejnych 7 Izba miała prawo dokooptować do swego składu ${ }^{94}$. Pierwszym prezesem Izby był dr Henryk Kolischer, po jego rezygnacji dr Marcin Szarski (przewodniczaccy rady nadzorczej Polskiego Banku Przemysłowego, senator RP) ${ }^{95}$. W Izbie Przemysłowo-Handlowej działali przeważnie kupcy polscy oraz pewna grupa kupców narodowości ukraińskiej i żydowskiej. Wiceprezesami Izby kierującymi pracami sekcji handlowej byli Julian Schayer (kupiec tekstylny) i Henryk Suesser (Bank Hipoteczny) ${ }^{96}$.

Członkowie Kongregacji Kupieckiej otrzymali pięć miejsc, Syndykat Interesantów Drzewnych - trzy, po jednym: Zwiazek Kupców Zbożem, Przetworami i Produktami Rolnemi, Związek Eksporterów Chmielu, Centralny Związek Kupców i Fabrykantów, Wschodnio-Małopolski Związek Eksporterów Jaj, Lwowskie Stowarzyszenie Kupców, Towarzystwo Przedstawicieli Handlowych, Związek Eksporterów Lnu i Konopi, dwa - Stowarzyszenie Polskich Kupców i Przemysłowców Województw

\footnotetext{
${ }_{92}$ B.T. Несторович, dz. cyt., s. 118.

${ }^{93}$ Przewodnik przemystu $i$ handlu polskiego, red. L. Paczewski, Warszawa 1926, s. $682-683$.

${ }_{94}$ Tamże, s. 247-248.

95 „Wiadomości Gospodarcze Izby Przemysłowo-Handlowej we Lwowie” 1932, nr 13.

96 „Wiadomości Gospodarcze Izby Przemysłowo-Handlowej we Lwowie” 1935, nr 9.
} 
Południowo-Wschodnich, a trzy - Związek Kupców Ukraińskich ${ }^{97}$. Jednak prasa ukraińska krytycznie oceniła skład komisji wyborczej (to według niej mogło zmniejszyć liczbę miejsc przyznanych członkom SUK): „Ogłoszony przez rząd skład komisji wyborczej daje nam wiele do myślenia. W tej komisji nie ma żadnego Ukraińca..." ${ }^{98}$. Ale też w prasie nakłaniano kupców ukraińskich do przystępowania do SUK, ponieważ w następnych latach Związek może otrzymać więcej miejsc dla swoich członków w Izbie Przemysłowo-Handlowej Lwowa.

Gazeta „Diło” pisała, że Warszawa lekceważy lwowską Izbę Przemysłowo-Handlowa, gdzie wpływ podzielono między kupców polskich i żydowskich. Natomiast na łamach „Tygodnika Handlowego” pojawiło się kilka artykułów z sugestią rezygnacji z wyborów do izb przemysłowo-handlowych i powoływania ich członków w drodze nominacji przez władze państwowe i organizacje gospodarcze ${ }^{99}$.

Izba podejmowała problemy związane $\mathrm{z}$ funkcjonowaniem i rozwojem handlu i przemysłu na terytorium województw: lwowskiego, tarnopolskiego i stanisławowskiego ${ }^{100}$. Utrzymywała stały kontakt z władzami regionalnymi i gospodarczymi, opiniowała projekty ustaw i rozporzadzeń, uczestniczyła w ustalaniu cen detalicznych, m.in. na szereg towarów spożywczych, opałowych oraz surowców. Zajmowała się organizacja szkolnictwa handlowo-przemysłowego i Targów Wschodnich. Starała się też walczyć o przestrzeganie zasad równej konkurencji we Lwowie. Przeciwstawiała się uprzywilejowaniu sklepów i przedsiębiorstw handlowych działajacych w lokalach należacych do miasta. Wskazywała, że najemcy tych lokali płacą zaniżone czynsze, dzięki czemu mogą sprzedawać po nieracjonalnie niższych cenach ${ }^{101}$. Zabiegała też o obniżenie opłat za energię elektryczną dla prowadzących działalność gospodarcza, a także domagała się poprawy skuteczności walki z handlem nielegalnym, obnośnym i ulicznym ${ }^{102}$.

${ }^{97}$ PAOL, zespół 1, Akta Lwowskiego Urzędu Wojewódzkiego, sygn. 1245, Spis organizacji kupieckich, t. 1, 1928 r., k. 197.

98 Tamże, k. 170.

99 „Tygodnik Handlowy”, 13 V 1935, s. 2.

100 Archiwalia izb przemystowo-handlowych. Stan $i$ perspektywy badań, red. K. Dąbrowski, Ryki 2012, s. 17.

101 Izba Przemysłowo-Handlowa. Plenarne zebranie..., s. 11-12.

102 PAOL, zespół 1, Akta Lwowskiego Urzędu Wojewódzkiego, sygn. 1935, Memoriał Związku Handlowców Bitym Drobiem o handlu nielegalnym w latach 1931-1932, k. 8 . 


\section{Bibliografia}

„Biuletyn Kongregacji Kupieckiej we Lwowie” 1939.

Dwudziestopięciolecie Lwowskiego Stowarzyszenia Kupców 1904-1929, Lwów 1929.

Filar T., Ukraińskie galicyjskie sfery gospodarcze w Drugiej Rzeczypospolitej, Kraków 2011.

Polski Zwiazek Handlowców: Towarzystwo Zapomogowe we Lwowie, 1920 -1930. Jednodniówka, Lwów 1930.

Spis organizacji gospodarczych opracowany na podstawie materiatów ankietowych zebranych przez izby przemystowo-handlowe, Warszawa 1936.

Sprawozdanie Stowarzyszenia Kupców i Przemystowców Polskich Województw Południowo-Wschodnich z czynności za rok 1936, Lwów 1937.

Sprawozdanie z czynności oraz o stanie gospodarczym w okręu Izby Przemysłowo-Handlowej we Lwowie w r. 1935, nakładem Izby Przemysłowo-Handlowej we Lwowie, Lwów 1936.

Sprawozdanie z czynności prezydium i wydziału Kongregacji Kupieckiej za czas od 16 października 1926 r. do 9 listopada 1929 r., Lwów 1929.

Stenograficzny protokót ankiety $w$ sprawie położenia gospodarczego przemysłu, handlu $i$ rękodzieła, odbytej $w$ dniach 21 i 22 listopada 1925 r. w Izbie Handlowej i Przemystowej we Lwowie, Lwów 1926.

Wierzbieniec W., Żydzi w województwie lwowskim w okresie międzywojennym. Zagadnienia demograficzne $i$ społeczne, Rzeszów 2003.

Andrij Bezsmertnyj

Lviv's associations of merchants in the interwar period (Summary)

The Lviv's Association of Merchants (founded already in the nineteenth century) was the largest among Jewish organisations established in Lviv. The Trade and Merchant Congregation associated a large part of local Polish merchants. There was also the Association of Ukrainian Merchants in Lviv. Aside from the associations of merchants, there were also trade and industrial organisations in the city (among their members were manufacturers and factory owners as well). Relations between the trade and merchants associations and the authorities were ambiguous - on the one hand they promoted state initiatives in the area of trade, and merchants cooperated with the Trade and Industry Chamber. On the other hand, however, they fought against a tax pressure. The local authorities sought to control all anti-tax activities of merchant associations, and tried to realise the idea of one single organisation of merchants in the city. 
Andrij Bezsmertnyj - dr, współpracownik naukowy, przewodnik muzealny lwowski w Muzeum Historii Religii, autor projektu badawczego: „Komercja i miasto (lata 20.-30. XX w.)" w ramach projektu „Lwów Interaktywny” (Centrum Historii Miejskiej Europy Środkowo-Wschodniej).

Andrij Bezsmertnyj - PhD, historian and researcher, employee at the Lviv Museum of Religious History, the author of a research project: "Commerce and the City (the 1920s and 1930s)" within the framework of the "Interactive Lviv" (the Center for Urban History of East central Europe).

E-mail: andriybezsmertny@hotmail.com. 